\title{
Analysis of Challenges and Countermeasures of Ideological and Political Education in Colleges and Universities in the New Era
}

\author{
Jun Wang \\ Chongqing Normal University, Chongqing, China \\ DOI: $10.32629 /$ jher.v2i6.569
}

\begin{abstract}
In the new era, ideological and political education in colleges and universities is faced with many opportunities and challenges. The core task of ideological and political education reform in colleges and universities is to innovate ideological and political education and enhance the pertinence and effectiveness of ideological and political education in the new era. The main ways of ideological and political education reform and innovation in colleges and universities are to explore the formation law of young students' ideological value in the new era, to innovate the ideas of ideological and political education, to improve the ideological and political quality of teachers, to enrich the content and form of ideological and political education, and to deepen the reform of educational evaluation in the new era. Based on the development and change of the international and domestic situation in the new era, we must explore the countermeasures of ideological and political education in accordance with the national conditions and the reality of colleges and universities.
\end{abstract}

Keywords: new era, ideological and political education in colleges and universities, challenges and countermeasures

The development level of higher education is an important symbol of a country's development level and stage, and highquality higher education is an important support for a country's core competitiveness. The country's need for high-quality higher education is more urgent than ever before, and the craving for science and technology and high-quality talents is stronger than ever before. Chinese colleges and universities and their ideological and political work should adhere to serving the people, serving the governance of the Communist Party of China, consolidating and developing the socialist system with Chinese characteristics, and serving the reform and opening up and socialist modernization ${ }^{[1]}$, which should be compatible with the goal of realizing the Chinese Dream of the great rejuvenation of the Chinese nation.

\section{Background and main challenges of ideological and political education in colleges and universities}

\subsection{The external environment of ideological and political education in colleges and universities has undergone profound changes}

The world is undergoing profound changes unseen in the past century. The global landscape is undergoing great changes. The United States has become the world's sole superpower, and the world has formed the framework of "one superpower with many powers". From the political perspective, world politics is moving towards multi-polarity. As the balance of international power changes and global challenges increase, it is an irresistible trend to strengthen global governance and promote reform of the global governance system. From the economic perspective, economic globalization is the general trend of the world economic development in the 21st century, and the international power is becoming more and more balanced. Economic globalization brings great challenges to the politics, economy, culture, society, ideology, security and other fields of all countries in the world. From the perspective of information technology, the internet and mobile internet further enhance the dissemination and connectivity of information. Under the background of economic globalization, political multi-polarization and network informationization, how to maintain the independence and security of national political culture is a major realistic task that all countries face.

\subsection{The political superstructure is challenged by the infiltration of western ideology}

It is the common choice of most countries in the world to actively integrate into globalization. China is an active advocate, participant and practitioner of globalization, and the proposer of the vision of a community with a shared future for mankind. Through economic, political and cultural exchanges, we can promote exchanges and mutual learning among civilizations and promote common development. The political civilization of China is essentially different from that of the West. The political system of capitalist countries essentially serves capital, while that of socialist countries essentially 
serves the people. In the long course of its development, China's development was blocked by some western powers, and the struggle in the field of ideology and ideological values becomes more intense. Since the 1990s, the United States has repeatedly claimed that it wants to change the world with American values and regards the expansion of American values as a major component of national security. China's political superstructure and ideology are also challenged by the infiltration of western ideology and values. Therefore, in the historical process of economic globalization, how to maintain the independence of the political superstructure and cope with the ideological and ideological value culture conflict brought by the process of globalization is a major subject that must be properly dealt with. Colleges and universities are the front positions in the field of ideology. One of the important tasks of ideological and political education in colleges and universities is to deal with the infiltration challenge of non-mainstream ideology.

\subsection{Teachers' ideological and political quality has a profound impact on the quality of talent cultivation}

In the process of talent cultivation in colleges and universities, teachers play a leading role, and their political stand, values and academic views will exert a profound influence on students' thoughts. At present, the ideological and political quality of college teachers need to be improved, some teachers' ideological and political quality is not high, because they haven't learned well of Xi Jinping's Socialism Thought with Chinese Characteristics for the New Era systematically, they have been lack of in-depth research on the road of socialism with Chinese characteristics, theory, system and culture and the lack of in-depth study, the ideological and political education literacy knowledge reserves is insufficient. In the process of education and teaching, their positions and views will have a positive or negative impact on students' ideas. In view of the current situation of ideological and political quality of teachers in colleges and universities, we should strengthen the education of political stance, political direction, political principles and political path, strengthen political identity, take the study of political theory as the normal state, and take the improvement of teachers' ideological and political quality as an eternal subject.

\subsection{Network media environment brings challenges to ideological and political education in colleges and universities}

In the current era, with the rapid development of the Internet and digital information technology, new media and we media have become the main channels for information dissemination in modern society. With the rapid development of new media and we media, network information has experienced explosive growth, all kinds of information to the direction of focus and development, have different attitudes and value orientation of information with the network space, there is a big uncertainty of the accuracy and reliability of the information, which have a huge impact and even misleading role for student's ideological cognition and values. Faced with the external environment of network information society, ideological and political education in colleges and universities is a huge uncontrollable variable, which increases the difficulty of ideological and political education in colleges and universities, and brings great challenges to ideological and political education in colleges and universities. How to adapt ideological and political education to the new trend of network information technology development is a major subject that must be faced and solved. In this context, colleges and universities need to think about how to use new media technology to spread political theory system, to guide students to pay attention to the development and change of world economic and political situation, to improve their ability of identifying, to consciously resist wrong social trend of thought or network opinions, and to maintain political stability.

\section{Main countermeasures of ideological and political education in colleges and universities in the new era}

\subsection{To adhere to innovative development, and constantly establish and improve the education system}

In the new era, students have active thinking, different personalities and nonconformity. Their world outlook, outlook on life and values are in a mature stage of development, with strong plasticity of their ideological values. Our work must follow the rules of work of colleges and universities, teaching law, laws of ideological and political education, students' growth, improve the "all people, whole process, all-round" education system, improve "the ten talents cultivating system" including the process education, scientific research education, practice education, culture education, network education, psychological education, funding, management and service. To promote all-round progress of ideological and political education in colleges and universities, we should teach students in accordance with their aptitude and implement policies based on their own characteristics, highlight pertinence, systematization, coordination and effectiveness. Colleges and universities 
should strengthen the organization and leadership of ideological and political education, administration departments should consolidate the functions and responsibilities of ideological and political education, and all staff should assume different educational responsibilities. It is necessary to strengthen the guarantee of conditions, establish and improve the working mechanism, improve the evaluation index system, regularly evaluate the effectiveness of ideological and political education, and form a closed-loop tracking feedback system.

\subsection{To innovate educational ideas and enhance the initiative of ideological and political education in colleges and universities.}

The renewal of ideas is the forerunner of the innovation of ideological and political education. First, to strengthen the leading consciousness. It is necessary to establish the core position of ideological and political education in personnel training in colleges and universities, adhere to and consolidate the guiding position of Marxism in colleges and universities, adhere to the cultivate talents with Xi Jinping's Thought on Socialism with Chinese Characteristics for a New Era, and deeply understand and grasp the great significance, rich connotation, and core significance of the new thought, take the initiative to occupy the position of public opinion, adhere to the use of correct public opinion guidance. The elements of ideological and political education should be integrated into students' learning space, living space and practice space to strengthen the guidance of ideological education for students from multiple dimensions. Second, to dig the content system deeply. Ideological and political education in colleges and universities should not only stick to and consolidate its position, but also take the initiative to renew the educational content system. We need dig deeply the rich connotation and education element of ideological and political theory course, the rich connotation of the excellent and splendid culture of the Chinese nation. To construct several first-class subjects, first-class disciplines and excellent courses, find out the entry point of ideological and political education of each discipline, integrate the elements of ideological and political education into the process of education and teaching, strengthen the responsibility of teachers of professional courses, and give play to the important role of curriculum education. Third, to strengthen the sense of service. Colleges and universities should firmly establish the concept of taking students as the foundation and serving students to become talents. Ideological and political education should meet the actual needs of students, shape the students' ideal faith, stimulate students to set up the lofty ambition, pay attention to humanistic care, to help students solve their realistic problems including academic, funding and employment etc., to strengthen the psychological counseling, pay attention to solve the problems of psychological, love, emotion. Ideological education should be combined with solving students' practical problems, so as to dispel doubts and solve difficulties, so as to achieve the goal of persuading people with emotion and reasoning, and to promote students' harmonious and comprehensive development.

\subsection{To strengthen the working team and improve the quality of ideological and political education staffs}

General Secretary Xi Jinping stressed that teachers are engineers of the human soul and shoulder a sacred mission. The preacher himself must first be enlightened and faithful. College and university teachers should insist that educators receive education first, strive to become disseminators of advanced ideology and culture, supporters of the Party's governance, and better assume the responsibility of guiding and guiding the healthy growth of students. It is necessary to strengthen the construction of teachers' ethics, adhere to the unity of teaching and educating, words and deeds, attention to society, academic freedom and academic norms, and guide teachers to establish themselves, learn, teach and moral education by virtue ${ }^{[2]}$. The ideological and political work team should continue to learn and improve, deeply study the psychological characteristics, cognitive characteristics and growth rules of young students in the new era, and constantly optimize the education methods. In particular, it is necessary to strengthen teachers' ability and quality training in ideological and political education and master the means, arts and methods of ideological and political education. The course teachers should constantly improve their teaching methods, fully explore the ideological and political education elements contained in the courses, enhance the ideological, academic and innovative nature of the courses, enhance the knowledge, interest and interaction of the courses, and enhance the effect of education. We need continue to regard teachers' ethics as the primary standard, strengthen the evaluation of teachers' ideological and political quality, and promote the normalization and long-term improvement of teachers' ethics.

\subsection{To deepen students' self-education and improve their self-development ability}

Students are not only the object of education, but also the subject of ideological and political education. We should respect the law of ideological and political work and the law of students' growth, and innovate the model of students' self-education. Guide students to scientifically understand and grasp themselves, actively establish development goals and 
directions, give full play to their potential, pay attention to the summary and reflection of the growth process, enhance the consciousness of reflection, and develop the ability of self-examination. Give full play to the role of laws and regulations, school discipline and other institutional constraints to develop students' self-discipline. Make use of student associations of ideas, learning, psychology, capability and other aspects to vigorously cultivate students' self-help ability, to carry out extensive practical experience, hone ambition education, frustration education, enhance students' sense of self-improvement, to guide students to develop independent personality, improve the subject consciousness, complete self-shaping, cultivate students' ability of independent development, and strive to shape themselves into harmonious and confident people with sound personality, mental health and self-satisfaction.

\subsection{To improve the network legal moral system and create a good network cultural ecology}

With the accelerated development of network technology, human society has already entered the information age. Therefore, the Party committee and government should pay more attention to the profound impact of network environment on education. We need speed up legislation on the Internet, establish a sound legal system on the Internet, and strengthen online ethics. The Party committee and government should build a platform for network governance, enhance the credibility of network governance, and promote social fairness and justice. College and university network management departments should strengthen network management, improve rules and regulations, strive to build a healthy and progressive network culture, strengthen the management of new media and we media, and create a healthy network environment for the growth of students. We should adhere to advance with the times, actively apply new technology to empower the practice of ideological and political education, strengthen the application of new media technology, give full play to the role of network to strengthen realistic technology, vigorously promote the construction of smart campus, and constantly enhance the attractiveness and vitality of ideological and political education.

\subsection{To adhere to the people-oriented, and constantly deepen the reform of education evaluation}

We should continue to improve school evaluation, take the effectiveness of moral education as the fundamental criterion for judging all school work, resolutely overcome one-sided practices of valuing intellectual education over moral education and grades over quality, and promote the physical and mental health and all-round development of students. We should reform student evaluation and set up the concept of scientific talent. We should give priority to morality, and attach great importance to ability, and develop in an all-round way. We should provide education for everyone and in accordance with their aptitude, and integrate knowledge with practice. We should resolutely change the practice of mark students according to their scores, develop new methods for evaluating students' morality, intelligence, physical fitness, aesthetics, and work, and improve the comprehensive quality evaluation system. We should guide students to firm up their ideals and beliefs, cultivate patriotism, strengthen moral cultivation, increase their knowledge, cultivate the spirit of struggle, and enhance their overall quality. We should improve the evaluation of moral education, strengthen the evaluation of physical education, improve the evaluation of aesthetic education, strengthen the evaluation of labor education, timely feedback to the educational link, improve the weakness, so as to constantly improve the quality and level of ideological and political education in colleges and universities.

\section{Conclusion}

All in all, in the context of economic globalization, it is inevitable that a variety of ideological values and cultures in the world will be in turmoil. Ideological and political education should actively adapt to the development and changes of the situation, effectively respond to the challenges brought by economic globalization, political multi-polarization and information flattening, and fulfill the responsibilities and missions of education in the new era. Colleges and universities should adhere to moral cultivation, adhere to the integrity and innovation, constantly explore the means of ideological and political education, maintain the concentration of ideological and political education, and strive to improve the pertinence and timeliness of ideological and political education, so as to constantly cultivate more high-quality talents with all-round development of morality, intelligence, physique, beauty and labor.

\section{References}

[1] The CPC Central Committee and The State Council. Opinions on Strengthening and Improving Ideological and Political Work in the New Era [N]. People's Daily, 2021-07-13 (1).

[2] The CPC Central Committee and The State Council. Opinions on Comprehensively Deepening the Reform of Teacher Team Construction in the New Era [N]. People's Daily, 2018-02-03 (1). 